\title{
Bandcizer - A Tool to Assess Dosage of Elastic Band Exercises
}

\author{
Morzia Khatoon ${ }^{1 *}$ and C Prabu ${ }^{2}$ \\ ${ }^{1}$ MPT IInd Year, The Oxford College of Physiotherapy, India \\ ${ }^{2}$ Principal, The Oxford College of Physiotherapy, India
}

Submission: July 31, 2018; Published: August 09, 2018

*Corresponding author: Morzia Khatoon, MPT IInd Year, The Oxford College of Physiotherapy, Bangalore, India; Email: khatoon.morzia786@gmail.com

\section{Introduction}

Home based treatment or rehabilitation is one the most blooming and evolving trend among budding and established physiotherapists as it gives improvement in pain intensity, quality of life and muscle strength at the comfort of being at home. Home based exercises are often carried out by patients with help of home-based exercise equipment's. Bandcizer is a sensor for resistance Training. It helps to assess the dosage of Thera band resistance and Intensity Figure 1.

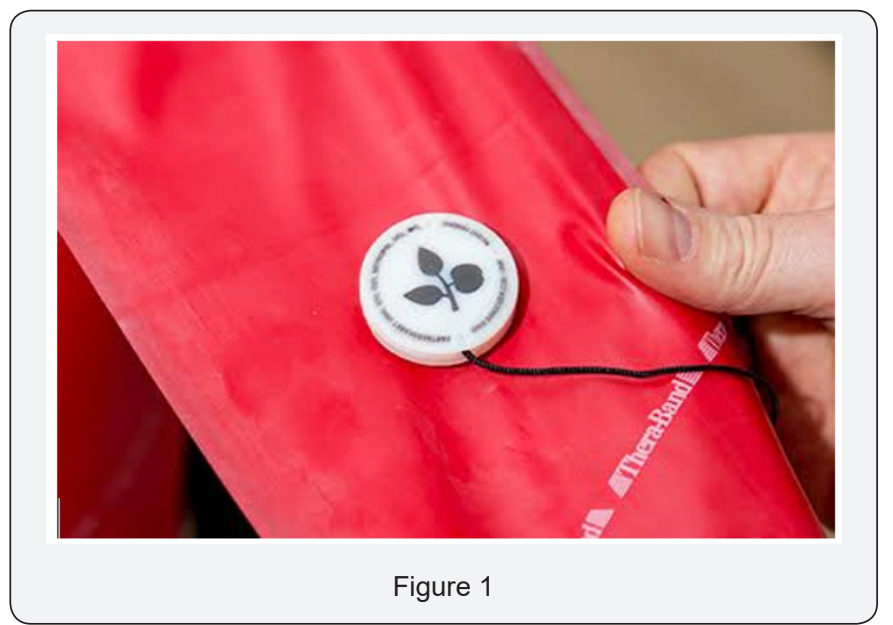

\section{What is the use of Bandcizer?}

Elastic band or resistive exercise ropes are used by many now a day as it provides the sufficient resistance for doing strengthening exercises. The duration, method, repetition and technique of using such exercises are a matter of concern for the physios who recommend home based exercises. Recent studies are suggesting the fact that secondary injuries following the practice of home-based exercises have increased drastically. It's unclear why such injuries happen and it's a serious which has to be looked into at the earliest.

\section{Founder}

BandCizer ApS is founded by Anders S. Sørensen \& Tim Bang A new commercially available sensor has been developed which automatically records and stores exercise data into its memory card or directly send into the mobile phone. The University Southern Denmark and the national Danish jointly developed "BANDCIZER ${ }^{\mathrm{TM}}$ ". This new sensor may help clinicians as well as researchers to monitor the Home-based exercise program with ease. The BandCizer is a small device (slightly larger than a quarter) that attaches to TheraBand resistance bands.

BandCizer is capable of automatically storing the data such as day, time and quantifying important aspects of exercise such as ROM and important details such as TUT (Time under tension). It measures the changes in thickness of the elastic band. It is equipped with a LSM3330 3D digital gyroscope with a sample rate of $20 \mathrm{~Hz}$. The data recorded by the sensor is sent to a computer directly in form of text files via Bluetooth.

\section{How it Works}

BandCizer 's 3D gyroscope measures rotation and angular velocity occurring around three axes: $\mathrm{x}, \mathrm{y}$ and $\mathrm{z}$. The positions of these axes are constant in the BandCizer and cannot be altered. For example: if rotation movement occurs around a vertical axis, the $\mathrm{x}$-axis of the gyroscope will register and record this movement, under the condition that the x-axis of the gyroscope is always positioned on thera-band to point vertically.

BandCizer App guides you towards optimal performance, compliance and progression your training and also provide interactive supervision with live bio-feedback, tailored for the individual [1-5].

\section{Advantages and Usage}

a) To increase quality in rehabilitation, sport and fitness. 
b) To boost motivation and provide interactive supervision.

c) To document compliance and visualise performance.

d) To share result with therapist (Figure 2).

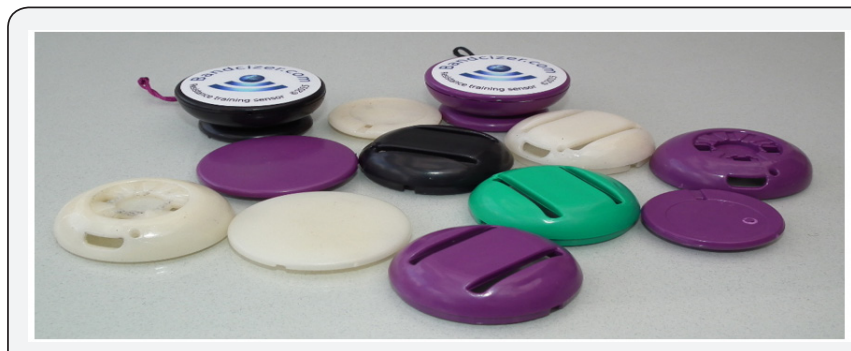

Figure 2

\section{References}

1. Rathleff MS, Bandholm T, McGirr KA, Harring SI, Sørensen AS, et al. New exercise-integrated technology can monitor the dosage and quality ofexercise performed against an elastic resistance band by adolescents with patellofemoral pain: an observational study. J Physiother 62(3): 159-163.

2. Osteras B, Osteras H, Torstensen TA, Vasseljen $O$ (2013) Dose-response effects of medical exercise therapy in patients with patellofemoral pain syndrome: a randomised controlled clinical trial. Physiotherapy 99(2): 126-131.

3. McGirr K, Harring SI, Kennedy TS, Pedersen MF, Hirata RP, et al. (2015) An Elastic exercise band mounted with a bandcizer ${ }^{\mathrm{TM}}$ can differentiate between commonly prescribed home exercises for the shoulder. The International Journal OF Sports Physical Therapy 10(3): 332-340.

4. Bollen JC, Dean SG, Siegert RJ, Howe TE, Goodwin VA (2014) A systematic review of measures of self-reported adherence to unsupervised homebased rehabilitation exercise programmes, and their psychometric properties. BMJ Open 4(6).

5. Rathleff MS, Thorborg K, Bandholm T (2013) Concentric and eccentric time-under-tension during strengthening exercises: validity and reliability of stretch-sensor recordings from an elastic exercise band. PLos One 8(6): e68172.

\section{Your next submission with Juniper Publishers will reach you the below assets}

- Quality Editorial service

- Swift Peer Review

- Reprints availability

- E-prints Service

- Manuscript Podcast for convenient understanding

- Global attainment for your research

- Manuscript accessibility in different formats

( Pdf, E-pub, Full Text, Audio)

- Unceasing customer service

Track the below URL for one-step submission https://juniperpublishers.com/online-submission.php 